\title{
LAWS OF IMAGE
}





\title{
LAWS of I MAGE
}

\section{PRIVACY AND PUBLICITY IN AMERICA}

\author{
Samantha Barbas
}

STANFORD LAW BOOKS

An Imprint of Stanford University Press

Stanford, California 


\section{Stanford University Press \\ Stanford, California}

(C) 2015 by the Board of Trustees of the Leland Stanford Junior University.

All rights reserved.

No part of this book may be reproduced or transmitted in any form or by any means, electronic or mechanical, including photocopying and recording, or in any information storage or retrieval system without the prior written permission of Stanford University Press.

Library of Congress Cataloging-in-Publication Data

Barbas, Samantha, author.

Laws of image : privacy and publicity in America / Samantha Barbas.

pages $\mathrm{cm}$

Includes bibliographical references and index.

ISBN 978-0-8047-9I44-I (cloth : alk. paper)

I. Privacy, Right of-United States-History. 2. Personality (Law)-

United States-History. 3. Libel and slander-United States-History.

4. Publicity (Law) —United States_-History. I. Title.

KFI262.B37 20I5

$342.7308^{\prime} 58$ - dc23

ISBN 978-0-8047-967I-2 (electronic)

2015010587

Typeset at Stanford University Press in Io/I5 Adobe Garamond 
To the memory of my mother and my father 
